Communication

\title{
Effective Synthesis of Nucleosides Utilizing $O$-Acetyl-Glycosyl Chlorides as Glycosyl Donors in the Absence of Catalyst: Mechanism Revision and Application to Silyl-Hilbert-Johnson Reaction
}

\author{
Chengyuan Liang *, Weihui Ju, Shunjun Ding, Han Sun and Gennian Mao * \\ Faculty of Pharmacy, Shaanxi University of Science \& Technology, 6 Xuefu Road, Xi'an 710021, China; \\ juweihui11521@sina.com (W.J.); 18792439483@163.com (S.D.); hansun0618@163.com (H.S.) \\ * Correspondence: chengyuanliang@gmail.com (C.L.); maogennian@sust.edu.cn or maogn@sust.edu.cn (G.M.); \\ Tel./Fax: +86-182-9249-0697 (C.L.); +86-29-8616-8088 (G.M.)
}

Academic Editor: Derek J. McPhee

Received: 20 November 2016; Accepted: 15 December 2016; Published: 5 January 2017

\begin{abstract}
An effective synthesis of nucleosides using glycosyl chlorides as glycosyl donors in the absence of Lewis acid has been developed. Glycosyl chlorides have been shown to be pivotal intermediates in the classical silyl-Hilbert-Johnson reaction. A possible mechanism that differs from the currently accepted mechanism advanced by Vorbrueggen has been proposed and verified by experiments. In practice, this catalyst-free method provides easy access to Capecitabine in high yield.
\end{abstract}

Keywords: nucleosides; glycosyl chiorides; $N$-glycosylation; catalyst free reaction; silyl-HilbertJohnson reaction

\section{Introduction}

Nucleoside analogs represent a potentially important class of antiviral anticancer agents [1-5] with antimicrobial and cholinesterase inhibitory activities [6-10] and are commonly used to treat hepatitis B virus [11,12], hepatitis C virus [13,14], herpes simplex [15,16], Human Immunodeficiency Virus (HIV) and neoplasms $[17,18]$. Zalcitabine $\left(2^{\prime}, 3^{\prime}\right.$-dideoxycytidine, ddc), Abacavir, Stavudine ( $2^{\prime}, 3^{\prime}$-didehydro-2' $3^{\prime}$-didehydro-2', $3^{\prime}$-dideoxythymidine, d4T), Didanosine $\left(2^{\prime}, 3^{\prime}\right.$-dideoxyinosine, ddI), Emtricitabine (FTC) and Zidovudine (azidothymidine, AZT) (Figure 1) are among the essential antiretroviral nucleoside analogue reverse transcriptase inhibitors (NRTIs) that are used to treat HIV / Acquired Immune Deficiency Syndrome (AIDS) infections [19]. In addition, some nucleoside analogues can function as both NRTIs and polymerase inhibitors for other viruses (e.g., Entecavir for hepatitis B) [20]. Less selective nucleoside analogues are used as chemotherapeutic agents to treat cancer, such as the orally administered Capecitabine [21], which is used to treat metastatic breast and colorectal cancers, and Cytarabine [22], which is mainly used in the therapy of white blood cell carcinomas (i.e., acute myeloid leukemia and non-Hodgkin's lymphoma) (Figure 1). Consequently, the development of new and more effective methods for developing nucleoside analogs is of significant commercial and academic interest.

Well-established strategies of preparing $N$-nucleosides include the following: (1) Fischer and Helferich reported that purine nucleosides could be synthesized by coupling purines with acetobromoglucose and applying silver or mercury salts as catalysts [23,24]; (2) the improved silyl-Hilbert-Johnson reaction $[25,26]$, the most widely used synthetic method, involves the coupling of per-silylated heterocyclic bases with per-acylated sugars in the presence of Friedel-Crafts catalysts (e.g., $\mathrm{SnCl}_{4}$ or TMSOTf). This reaction has been the dominant method for the preparation of pyrimidine, purine and other heterocyclic nucleosides. Despite these available methods $[8,9,27-30]$, a facile and 
green synthetic strategy, which avoids the use of costly and hazardous catalysts, for synthesizing nucleosides remains an urgent need.

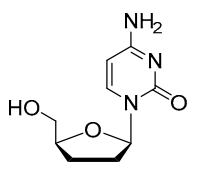

Zalcitabine
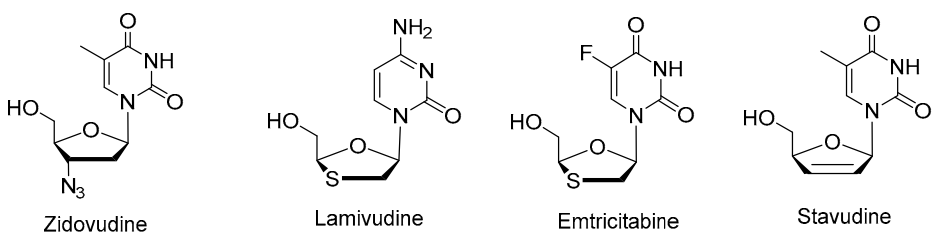

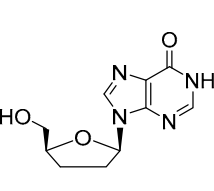

Didanosine

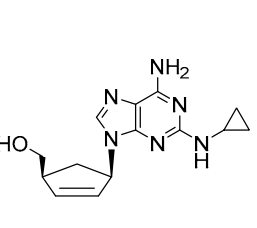

Abacavir

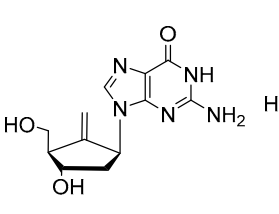

Entecavir

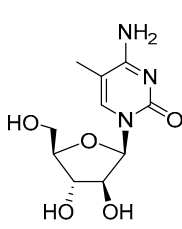

Cytarabine

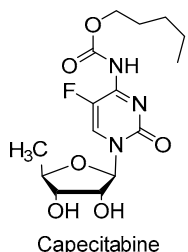

Figure 1. Structures of commonly used nucleoside drugs.

Since the introduction of the silyl-Hilbert-Johnson reaction by Iwai and Nishimura [31], diverse types of glycosyl donors have been applied to prepare nucleosides. Among these donors, 1-O-acetyl sugars are the most frequently used glycosyl donors. However, in all of these methods, a stoichiometric amount of a strong Lewis acid promoter (e.g., $\mathrm{SnCl}_{4}$, TMSOTf or $\mathrm{BF}_{3} \cdot \mathrm{OEt}_{2}$ ) is required to secure high-yielding $\mathrm{N}$-glycosylation. Notably, 1-Cl-acetyl sugars, inexpensive glycosyl donors, have rarely been employed in nucleoside synthesis, and a catalyst-free $\mathrm{N}$-glycosylation method utilizing 1-Cl-acetyl sugars as glycosyl donors has not been reported yet. Herein, we report the facile glycosylation of nucleobases employing 1-Cl-acetyl sugars as glycosyl donors under mild conditions in the absence of any additives.

\section{Results and Discussion}

Initially, we attempted to develop an ionic liquid-promoted method of $N$-glycosylation employing peracetylated D-ribofuranosyl chloride (1a) as the glycosyl donor. Disappointingly, ionic liquid was unsuitable for the labile silyl-pyrimidine in these preliminary attempts (Entries 6-8, Table 1). A farraginous mixture of products was produced, but no nucleoside was obtained, according to mass spectrometric analysis. In contrast, acetyl nucleoside (3a) was obtained with an unexpectedly high yield (95\%) when the reaction was carried out in the absence of catalyst (Entry 1, Table 1). The starting material peracetylated D-ribofuranosyl chloride (1a) was conveniently prepared by the reaction of per-acylated ribose with stoichiometric thionyl chloride (instead of the commonly used acetyl chloride) in the presence of catalytic glacial acetic acid in dry 1,2-dichloroethane at ambient temperature (Figure 2). Bis-silyl pyrimidine (2a) was obtained in a quantitative yield by treating thymine with Hexamethyldisilazane (HMDS) using a catalytic amount of ammonium sulfate in refluxing 1,2-dichloroethane (DCE). Gratifyingly, these important findings encouraged us to further explore the scope of the catalyst-free reaction.

Table 1. Optimization of reaction conditions for the synthesis of $3 a$.

\begin{tabular}{|c|c|c|c|c|}
\hline Entry & Solvent & Reaction Time (h) & Temprature $\left({ }^{\circ} \mathrm{C}\right)$ & Yield (\%) \\
\hline 1 & 1,2-Dichloroethane & 4 & 83 & 95 \\
\hline 2 & Toluene & 6 & 110 & 89 \\
\hline 3 & $\mathrm{MeCN}$ & 7 & 80 & 78 \\
\hline 4 & THF & 10 & 66 & 64 \\
\hline 5 & Ethanol & 10 & 78 & Trace \\
\hline 6 & {$\left[\mathrm{Bmim} \mathrm{BF}_{4}\right.$} & 8 & 90 & - \\
\hline 7 & {$[\mathrm{Bmim}] \mathrm{PF}_{6}$} & 8 & 90 & - \\
\hline 8 & {$[\mathrm{Bmim}] \mathrm{HSO}_{4}$} & 8 & 90 & - \\
\hline
\end{tabular}




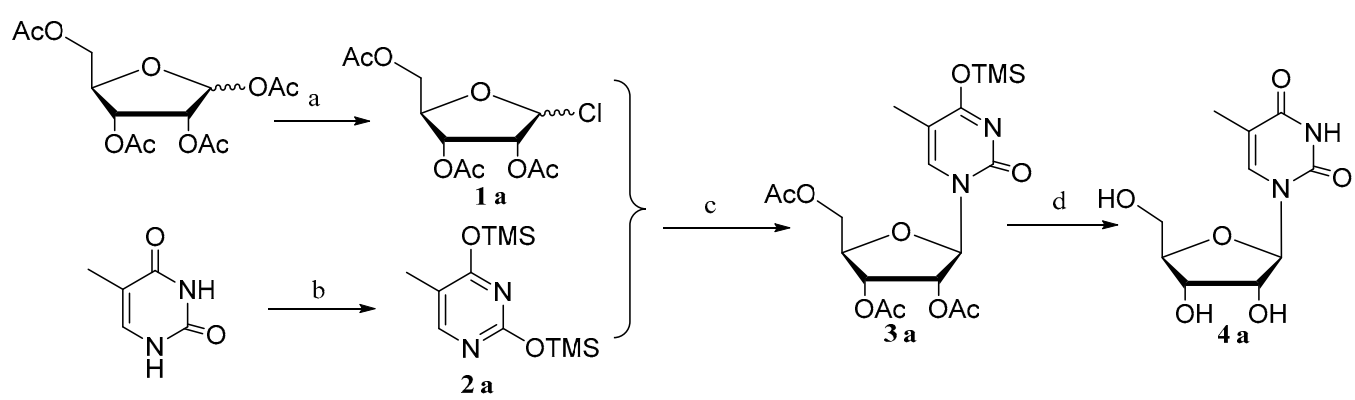

a: $\mathrm{SOCl}_{2} / \mathrm{AcOH} / \mathrm{DCM}$, rt, $5 \mathrm{~h}, 82 \%$; b: HMDS (Hexamethyldisilazane) $/\left(\mathrm{NH}_{4}\right)_{2} \mathrm{SO}_{4} / \mathrm{DCE}$, reflux, $4 \mathrm{~h}, 100 \%$; c: DCE, reflux, 4h, 95\%; d: $\mathrm{MeOH} / \mathrm{NH}_{3}$, rt, $6 \mathrm{~h}, 81 \%$.

Figure 2. Synthesis of ribosylthymine.

We commenced our study with a brief optimization of the reaction conditions, selecting peracetylated D-ribofuranosyl chloride (1a) and per-silylated thymine as starting materials. As shown in Table 1, a trace amount of 3a was obtained in a polar protic solvent (Entry 5). In contrast, reactions occurring in other solvents (i.e., DCE, $\mathrm{MeCN}$, THF and toluene) at reflux afforded the desired product in moderate to excellent yields (Entries 1-4). As mentioned above, none of the desired product (3a) was obtained in ionic liquids (Entries 6-8).

With the optimal reaction conditions in hand, we investigated the reactions of 1-Cl-acetyl sugars $\mathbf{1 a}$ and $\mathbf{1} \mathbf{b}$ with a variety of per-silylated nucleobases ( $\mathbf{2 a}-\mathbf{2} \mathbf{g})$ using 1,2-dichloroethane (DCE) as solvent at $83{ }^{\circ} \mathrm{C}$ to establish the generality of the transformation. Compound $\mathbf{1 b}$ was obtained according to the method used to prepare $1 \mathbf{a}$, and per-silylated nucleobases $\mathbf{2 b}-\mathbf{2 g}$ were prepared in the same manner as 2a. Reaction completion (after 6-14 h) was determined by thin-layer chromatography (TLC). The results are shown in Figure 3. The glycosylation of per-silylated pyrimidine nucleobases $\mathbf{2 a}-\mathbf{2} \mathbf{d}$ with peracetylated D-ribofuranosyl chloride $\mathbf{1 a}$ afforded the desired $\beta$-nucleosides $\mathbf{3 a - 3 e}$ in moderate to excellent yields (64\%-95\%).The electron-withdrawing group (-F) on silylated 5-fluorouracil led to a decrease in the yield of the $N$-glycosylation reaction (compared to $\mathbf{2 a}$ and $\mathbf{2 b}$ ), likely due to the reduced nucleophilicity of $\mathbf{2 c}$. Purine nucleobases $\mathbf{2 f}$ and $\mathbf{2 g}$ generated the corresponding products $3 \mathbf{f}$ and $\mathbf{3 g}$ in poor yields (14\% and $18 \%$ ), which might have partially been due to difficulties in purification. The coupling of per-silylated pyrimidine nucleobases $\mathbf{2 a}-\mathbf{2 e}$ with tetra- $O$-acetyl glucopyranosyl chloride $\mathbf{1 b}$ led to a mixture of $\alpha / \beta$ nucleoside stereoisomers $3 \mathbf{h}-\mathbf{3 l}$ in relatively low yields $(14 \%-44 \%)$, the ratios determined by the chiral column of HPLC. In addition, $2 \mathrm{f}$ and $\mathbf{2 g}$ failed to generate corresponding products $3 \mathrm{~m}$ and $3 \mathrm{n}$, instead resulting in a complex mixture.

Perhaps the most striking demonstration of the utility of this reaction is demonstrated by the preparation of Capecitabine (an oral medication for treating breast cancers). As depicted in Figure 4, key intermediate $\mathbf{6} \mathbf{a}$ was obtained employing $\mathbf{4 \mathbf { b } ^ { \prime }}$ and $\mathbf{5} \mathbf{a}$ as starting materials with improved yield (86\%, compared to $75 \%$ using a traditional silyl-Hilbert-Johnson reaction) and a significant decrease in the reaction time ( $4 \mathrm{~h}$ compared to $8 \mathrm{~h}$ ) [32].

Intermediate $\mathbf{A}$ is quite similar to intermediate $\mathbf{B}$ formed under silyl-Hilbert-Johnson reaction conditions, according to the classical mechanism (path a in Figure 5) initially proposed by Vorbrueggen [33,34]. Combining this structure with our findings, the efficient and high-yielding reactions described above, indicates that intermediate $\mathbf{A}$ can be generated smoothly from peracetylated D-ribofuranosyl chloride 1a. Consequently, we postulate that path $\mathbf{b}$ (Figure 6) may be an alternative course of the classical mechanism (path a) of the silyl-Hilbert-Johnson reaction. To verify our hypothesis, per-acetyl ribose was treated with $\mathrm{SnCl}_{4}$ in the absence of per-silylated nucleobase $\mathbf{2 a}$, according to silyl-Hilbert-Johnson reaction conditions. As expected, peracetylated D-ribofuranosyl chloride 1a was obtained in relatively high yield (56\%) after stirring for $3 \mathrm{~h}$ at ambient temperature. The equivalent stoichiometric silyl-thymidine $\mathbf{2 a}$ without Lewis acid catalyst was added to a solution of peracetylated D-ribofuranosyl chloride 1a in DCE and the resulting mixture was stirred for $16 \mathrm{~h}$ at 
ambient temperature (Figure 6). Upon completion of the reaction, the crude product 3a was purified by column chromatography to give a moderate isolated yield of $43 \%$. Therefore, the silyl-Hilbert-Johnson reaction might be characterized by two available routes, path a and path $b$. The mechanism is shown in Figure 6.

Figure 5 lays out a plausible mechanism for this catalyst-free $N$-glycosylation method. First, 1a undergoes intramolecular cyclization to give cyclic oxonium ion A; this process occurs without any catalyst. Subsequently, A reacts with $\mathbf{2 a}$ via an intermolecular nucleophilic substitution reaction to deliver intermediate $\mathbf{B}$, which is converted to the target product $\mathbf{3 a}$ after the addition of water. Acidic gas, possibly from the hydrolysis of TMSCl in air, was generated in the reaction, which supports the proposed mechanism.

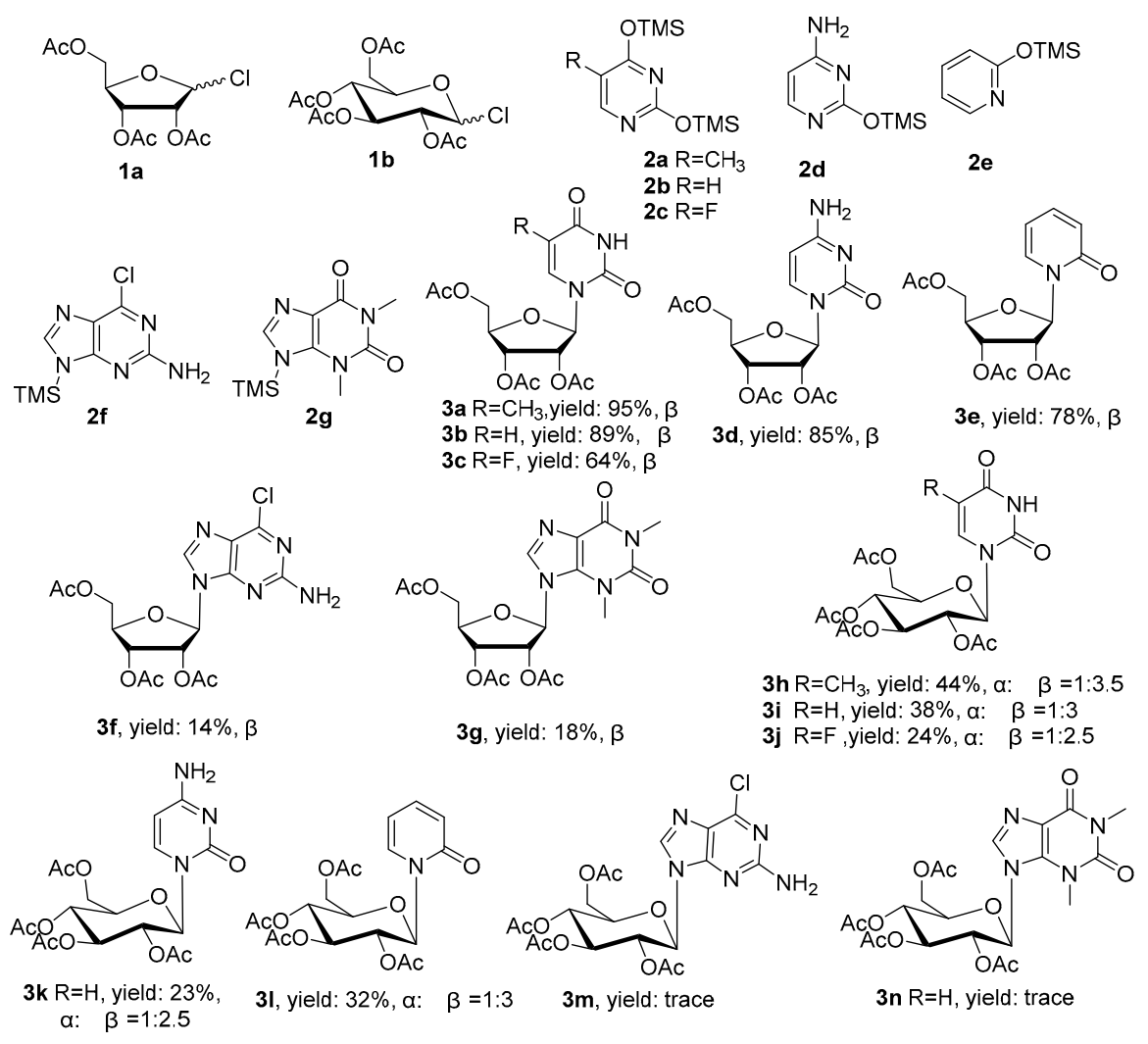

Figure 3. Nucleoside synthesis employing acetyl-glycosyl chlorides as glycosyl donors.

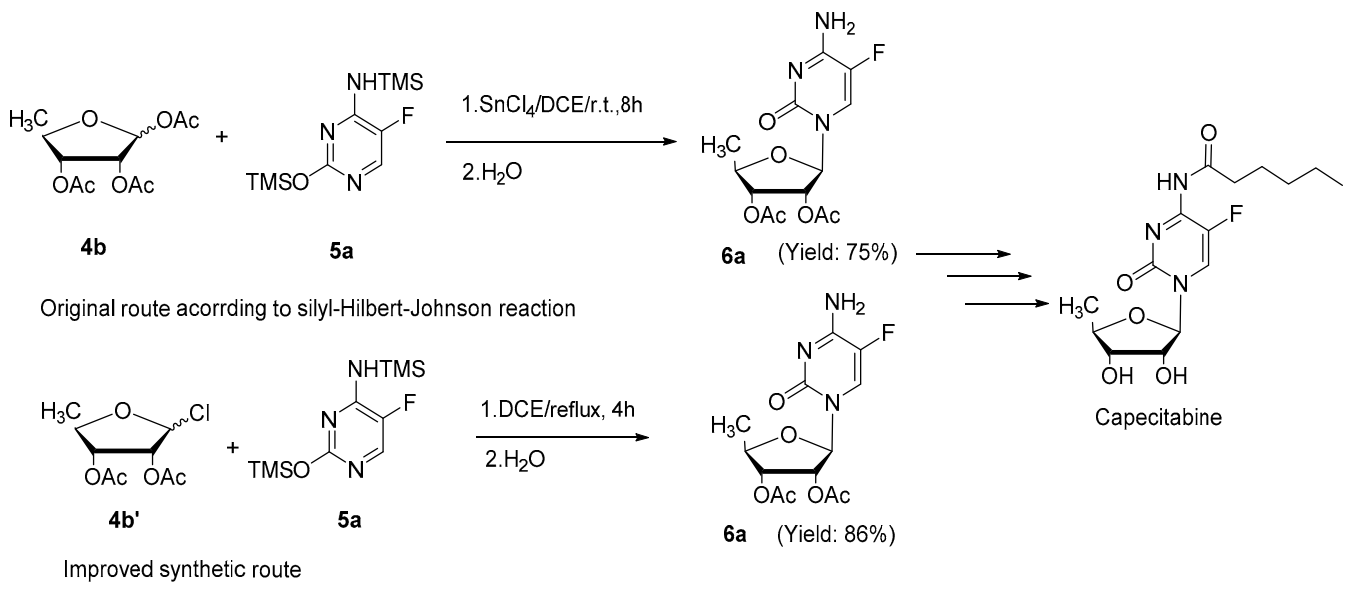

Figure 4. Application to the preparation of Capecitabine. 


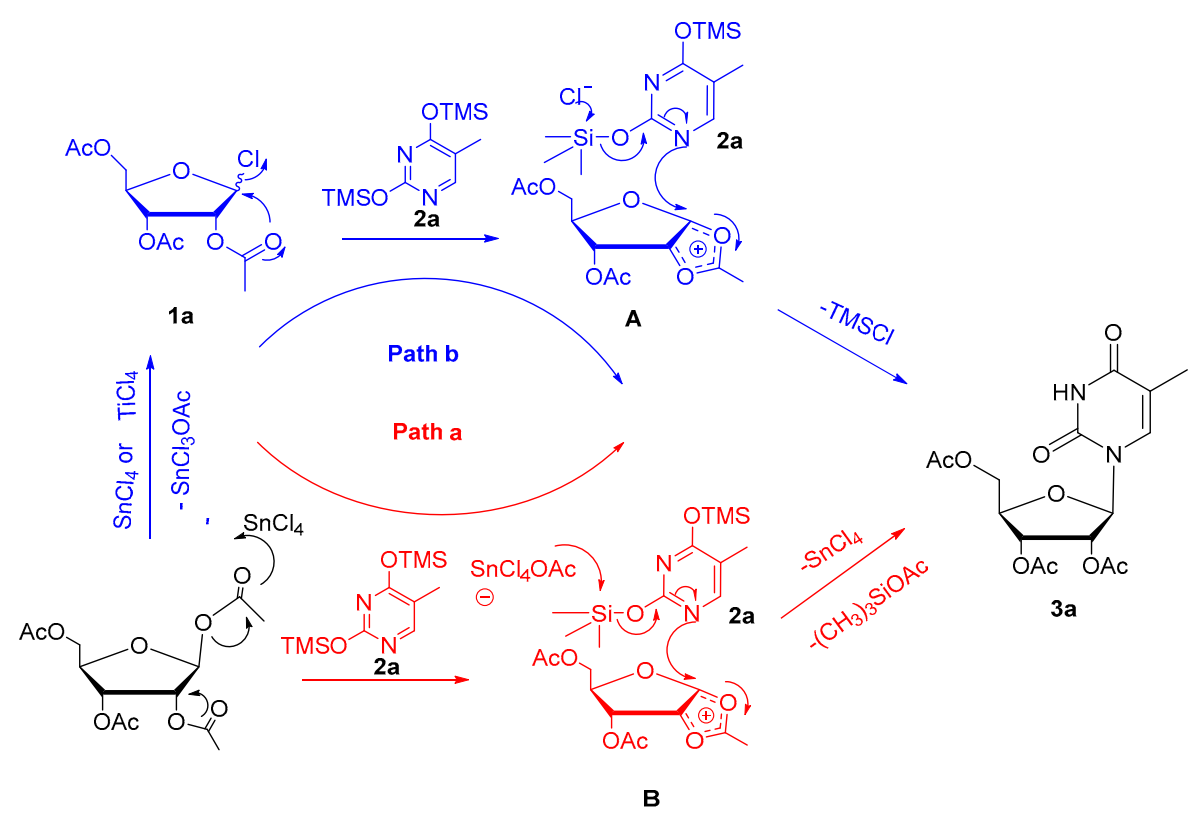

Figure 5. Mechanism for silyl-Hilbert-Johnson reaction.

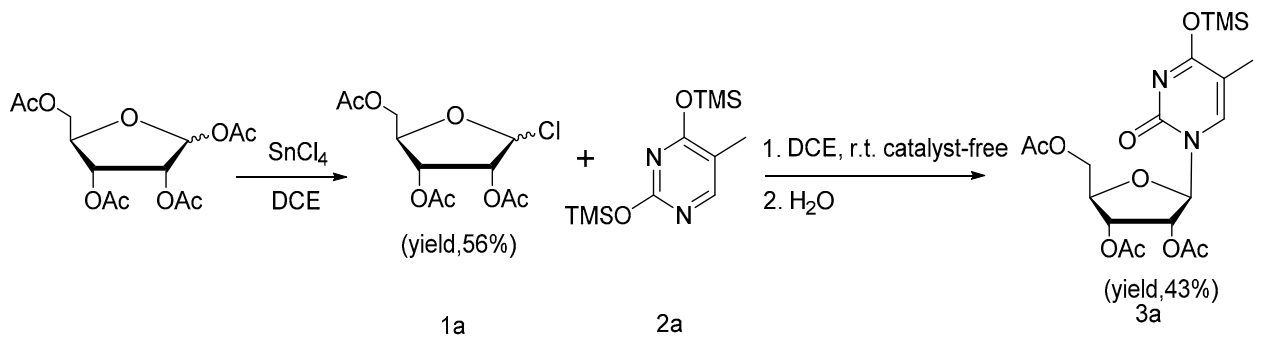

Figure 6. Verification of speculated path b of silyl-Hilbert-Johnson reaction.

\section{Experimental Section}

All substrates and solvents were commercially available and were purified before use. Reactions were carried out under $\mathrm{N}_{2}$ using standard Schlenk techniques. Mass spectra were recorded on a mass spectrometer using electron impact ionization (EI) techniques. Compounds were visualized under UV lamp $(254 \mathrm{nM}) .{ }^{1} \mathrm{H}-\mathrm{NMR}$ and ${ }^{13} \mathrm{C}-\mathrm{NMR}$ spectra were obtained on a Bruker AV-300 NMR spectrometer (Zurich Region, Switzerland). Analytical TLC was carried out with plates pre-coated with silicagel $60 \mathrm{~F}_{254}(0.25 \mathrm{~mm}$ thick). The identity of the products was established by comparing their physical and spectral data with those of reported compounds [35-41]. See more details in Supplementary Materials.

\section{General Experimental Procedure for Synthesis of Acetyl Ribosylthymine (3a)}

Synthesis of 1a: Ribofuranose tetraacetate $(20 \mathrm{mmol})$ was mixed with thionyl chloride $(12 \mathrm{mmol})$ and glacial acetic acid $(0.1 \mathrm{mmol})$ under stirring in 1,2-dichloroethane $(50 \mathrm{~mL})$ for $6 \mathrm{~h}$ at room temperature. The obtained product was purified by column chromatography $\left(\mathrm{MeOH} / \mathrm{CH}_{2} \mathrm{Cl}_{2}\right.$, $1: 10 \mathrm{v} / \mathrm{v})$. Compound $\mathbf{1} \mathbf{b}$ was prepared under the same conditions with a longer reaction time $(10 \mathrm{~h})$.

Synthesis of 2a: A mixture of thymidine (10 mmol), HMDS $(12 \mathrm{mmol})$ and ammonium sulphate $(0.1 \mathrm{mmol})$ was stirred in refluxing 1,2-dichloroethane $(50 \mathrm{~mL})$ for $3 \mathrm{~h}$. When the reaction mixture became translucent, it was concentrated in vacuo to provide $\mathbf{2 a}$. Compounds $\mathbf{2} \mathbf{b}-\mathbf{f}$ were prepared under the same conditions with varying reaction times $(4-8 \mathrm{~h})$.

Synthesis of 3a: To a solution of silyl-thymidine $(10 \mathrm{mmol})$ in DCE $(100 \mathrm{~mL})$ was added 1a (12 mmol diluted in $25 \mathrm{~mL}$ DCE) dropwise at room temperature. The resulting mixture was stirred 
for $4 \mathrm{~h}$ at $83{ }^{\circ} \mathrm{C}$. Upon completion of the reaction, as indicated by TLC ( $n$-hexane/ethylacetate: 40:60), the reaction mixture was cooled to room temperature and $\mathrm{H}_{2} \mathrm{O}(50 \mathrm{~mL})$ was added, and the mixture was, stirred for $0.5 \mathrm{~h}$. The resulting reaction mixture was diluted with DCE (50 mL) and washed with water and saturated $\mathrm{NaCl}$ solution. The organic layer was dried with $\mathrm{MgSO}_{4}$ and filtered. The filtrate was concentrated under reduced pressure and purified by column chromatography $\left(\mathrm{MeOH} / \mathrm{CH}_{2} \mathrm{Cl}_{2}\right.$, $1: 10 v / v)$ to obtain an analytical sample for a total yield of $95 \%$.

\section{Conclusions}

In summary, we have developed an efficient and straightforward synthesis of N-nucleosides employing glycosyl chlorides as glycosyl donors in the absence of traditional Lewis acid catalysts, which significantly expands the versatility of the silyl-Hilbert-Johnson reaction. The higher yields, mild reaction conditions, ease of purification, economic availability of the starting materials and avoidance of a catalyst make this an ecologically friendly procedure for the synthesis of nucleosides. A novel dual-path mechanism for the silyl-Hilbert-Johnson reaction has also been proposed and validated experimentally. In addition to Capecitabine, further expansions of the reaction scope and synthetic applications of this methodology are in progress in our laboratory.

Supplementary Materials: Supplementary materials can be accessed at: http:/ /www.mdpi.com/1420-3049/22/ $1 / 84 /$ s1.

Acknowledgments: This work was supported by the National Natural Science Foundation of China (Grant No. 81602967) and the China Postdoctoral Science Foundation (Grant No. 2016M592898XB), the Shaanxi Postdoctoral Science Foundation (2015), the Basic Research Plan of the Education Department of Shaanxi Province National (Grant No. 15JK1076), the College Students' Innovative Entrepreneurial Training Program (Grant No. 201510708172, 201610708019). We appreciate the support from Center for Instrumental Analysis, China Pharmaceutical University, for their contribution to the structural confirmation.

Author Contributions: Chengyuan Liang and Weihui Ju were the main writers of this article, Shunjun Ding has finished and Han Sun have finished the synthesis of nucleosides, Gennian Mao supervised our experiments and provided the original idea.

Conflicts of Interest: The authors declare no conflict of interest.

\section{References}

1. Crespan, E.; Garbelli, A.; Amoroso, A.; Maga, G. Exploiting the Nucleotide Substrate Specificity of Repair DNA Polymerases to Develop Novel Anticancer Agents. Molecules 2011, 16, 7994-8019. [CrossRef] [PubMed]

2. Robak, T.; Korycka, A.; Lech-Maranda, E.; Robak, P. Current Status of Older and New Purine Nucleoside Analogues in the Treatment of Lymphoproliferative Diseases. Molecules 2009, 14, 1183-1226. [CrossRef] [PubMed]

3. Yu, Q.; Schwidom, D.; Exner, A.; Carlsen, P. Synthesis of Novel Homo-N-Nucleoside Analogs Composed of a Homo-1,4-Dioxane Sugar Analog and Substituted 1,3,5-Triazine Base Equivalents. Molecules 2008, 13, 3092-3106. [CrossRef] [PubMed]

4. Yu, Q.; Carlsen, P. Enantioselective Synthesis of Homo-N-Nucleosides Containing a 1,4-Dioxane Sugar Analog. Molecules 2008, 13, 2962-2974. [CrossRef] [PubMed]

5. Lin, S.-K.; Rosemeyer, H. Perspectives in Nucleoside and Nucleic Acid Chemistry. Molecules 2001, 6, 1030-1033.

6. Rachakonda, S.; Cartee, L. Challenges in Antimicrobial Drug Discovery and the Potential of Nucleoside Antibiotics. Curr. Med. Chem. 2004, 11, 775-793. [CrossRef] [PubMed]

7. Vitali, L.A.; Petrelli, D.; Lambertucci, C.; Prenna, M.; Volpini, R.; Cristalli, G. In vitro antibacterial activity of different adenosine analogues. J. Med. Microbiol. 2012, 61, 525-528. [CrossRef] [PubMed]

8. Xavier, N.M.; Schwarz, S.; Vaz, P.D.; Csuk, R.; Rauter, A.P. Synthesis of Purine Nucleosides from D-Glucuronic Acid Derivatives and Evaluation of Their Cholinesterase-Inhibitory Activities. Eur. J. Org. Chem. 2014, 2014, 2770-2779. [CrossRef]

9. Schwarz, S.; Csuk, R.; Rauter, A.P. Microwave-assisted synthesis of novel purine nucleosides as selective cholinesterase inhibitors. Org. Biomol. Chem. 2014, 12, 2446-2456. [CrossRef] [PubMed] 
10. Batista, D.; Schwarz, S.; Loesche, A.; Csuk, R.; Costa, P.J.; Oliveira, M.C.; Xavier, N.M. Synthesis of glucopyranos- $6^{\prime}$-yl purine and pyrimidine isonucleosides as potential cholinesterase inhibitors. Access to pyrimidine-linked pseudodisaccharides through Mitsunobu reaction. Pure Appl. Chem. 2016, 88, 363-379. [CrossRef]

11. Lin, T.S.; Luo, M.Z.; Liu, M.C.; Pai, S.B.; Dutschman, G.E.; Cheng, Y.C. Synthesis and biological evaluation of $2^{\prime}, 3^{\prime}$-dideoxy-L-pyrimidine nucleosides as potential antiviral agents against human immunodeficiency virus (HIV) and hepatitis B virus (HBV). J. Med. Chem. 1994, 37, 798-803. [CrossRef] [PubMed]

12. Ma, T.; Pai, S.B.; Zhu, Y.L.; Lin, J.S.; Shanmuganathan, K.; Du, J.; Wang, C.; Kim, H.; Newton, M.G.; Cheng, Y.C. Structure-activity relationships of 1-(2-deoxy-2-fluoro- $\beta$-L-arabino-furanosyl) pyrimidine nucleosides as anti-hepatitis B virus agents. J. Med. Chem. 1996, 39, 2835-2843. [CrossRef] [PubMed]

13. Suzich, J.; Tamura, J.; Palmer-Hill, F.; Warrener, P.; Grakoui, A.; Rice, C.; Feinstone, S.; Collett, M. Hepatitis C virus NS3 protein polynucleotide-stimulated nucleoside triphosphatase and comparison with the related pestivirus and flavivirus enzymes. J. Virol. 1993, 67, 6152-6158. [PubMed]

14. Klumpp, K.; Lévêque, V.; Le Pogam, S.; Ma, H.; Jiang, W.R.; Kang, H.; Granycome, C.; Singer, M.; Laxton, C.; Hang, J.Q. The novel nucleoside analog R1479 (4'-azidocytidine) is a potent inhibitor of NS5B-dependent RNA synthesis and hepatitis C virus replication in cell culture. J. Biol. Chem. 2006, 281, 3793-3799. [CrossRef] [PubMed]

15. Fyfe, J.; Keller, P.; Furman, P.; Miller, R.; Elion, G. Thymidine kinase from herpes simplex virus phosphorylates the new antiviral compound, 9-(2-hydroxyethoxymethyl) guanine. J. Biol. Chem. 1978, 253, 8721-8727. [PubMed]

16. Smith, K.O.; Galloway, K.S.; Kennell, W.L.; Ogilvie, K.K.; Radatus, B.K. A new nucleoside analog, 9-[[2-hydroxy-1-(hydroxymethyl)ethoxyl] methyl] guanine, highly active in vitro against herpes simplex virus types 1 and 2. Antimicrob. Agents Chemother. 1982, 22, 55-61. [CrossRef] [PubMed]

17. Vince, R.; Hua, M.; Brownell, J.; Daluge, S.; Lee, F.; Shannon, W.M.; Lavelle, G.C.; Qualls, J.; Weislow, O.S.; Kiser, R. Potent and selective activity of a new carbocyclic nucleoside analog (carbovir: NSC 614846) against human immunodeficiency virus in vitro. Biochem. Biophys. Res. Commun. 1988, 156, 1046-1053. [CrossRef]

18. Rabkin, C. AIDS and cancer in the era of highly active antiretroviral therapy (HAART). Eur. J. Cancer 2001, 37, 1316-1319. [CrossRef]

19. Mallal, S.A.; John, M.; Moore, C.B.; James, I.R.; McKinnon, E.J. Contribution of nucleoside analogue reverse transcriptase inhibitors to subcutaneous fat wasting in patients with HIV infection. Aids 2000, 14, 1309-1316. [CrossRef] [PubMed]

20. Lai, C.L.; Shouval, D.; Lok, A.S.; Chang, T.T.; Cheinquer, H.; Goodman, Z.; DeHertogh, D.; Wilber, R.; Zink, R.C.; Cross, A. Entecavir versus lamivudine for patients with HBeAg-negative chronic hepatitis B. N. Engl. J. Med. 2006, 354, 1011-1020. [CrossRef] [PubMed]

21. Miwa, M.; Ura, M.; Nishida, M.; Sawada, N.; Ishikawa, T.; Mori, K.; Shimma, N.; Umeda, I.; Ishitsuka, H. Design of a novel oral fluoropyrimidine carbamate, capecitabine, which generates 5 -fluorouracil selectively in tumours by enzymes concentrated in human liver and cancer tissue. Eur. J. Cancer 1998, 34, 1274-1281. [CrossRef]

22. Darrington, D.L.; Vose, J.M.; Anderson, J.R.; Bierman, P.J.; Bishop, M.R.; Chan, W.C.; Morris, M.E.; Reed, E.C.; Sanger, W.G.; Tarantolo, S.R. Incidence and characterization of secondary myelodysplastic syndrome and acute myelogenous leukemia following high-dose chemoradiotherapy and autologous stem-cell transplantation for lymphoid malignancies. J. Clin. Oncol. 1994, 12, 2527-2534. [PubMed]

23. Yamaoka, N.; Aso, K.; Matsuda, K. New Syntheses of Nucleosides. 1a The Syntheses of Glycopyranosides of Purines, Pyrimidine, and Benzimidazole. J. Org. Chem. 1965, 30, 149-152. [CrossRef]

24. Jungmann, O.; Pfleiderer, W. A new efficient method in nucleoside synthesis. Tetrahedron Lett. 1996, 37, 8355-8358. [CrossRef]

25. Niedballa, U.; Vorbrüggen, H. Synthesis of nucleosides 17. A general synthesis of N-glycosides. 6. On the mechanism of the stannic chloride catalyzed silyl Hilbert-Johnson reaction. J. Org. Chem. 1976, 41, 2084-2086. [CrossRef] [PubMed]

26. Vorbrüggen, H.; Krolikiewicz, K.; Bennua, B. Nucleoside syntheses, XXII1) Nucleoside synthesis with trimethylsilyl triflate and perchlorate as catalysts. Chem. Ber. 2007, 114, 1234-1255. [CrossRef]

27. Catry, M.; Madder, A. Synthesis of Functionalised Nucleosides for Incorporation into Nucleic Acid-Based Serine Protease Mimics. Molecules 2007, 12, 114-129. [CrossRef] 
28. Qu, G.; Zhang, Z.; Guo, H.; Geng, M.; Xia, R. Microwave-promoted Facile and Efficient Preparation of N-(alkoxycarbonylmethyl) Nucleobases-Building Blocks for Peptide Nucleic Acids. Molecules 2007, 12, 543-551. [CrossRef] [PubMed]

29. Yu, Q.; Carlsen, P. Synthesis of Polynucleotide Analogs Containing a Polyvinyl Alcohol Backbone. Molecules 2008, 13, 701-715. [CrossRef] [PubMed]

30. Lanver, A.; Schmalz, H.-G. Microwave-Assisted Amination of a Chloropurine Derivative in the Synthesis of Acyclic Nucleoside Analogues. Molecules 2005, 10, 508-515. [CrossRef] [PubMed]

31. Nishimura, T.; Shimizu, B. Studies on Synthetic Nucleosides. Agric. Biol. Chem. Tokyo 1964, 28, $224-229$.

32. Shimma, N.; Umeda, I.; Arasaki, M.; Murasaki, C.; Masubuchi, K.; Kohchi, Y.; Miwa, M.; Ura, M.; Sawada, N.; Tahara, $\mathrm{H}$. The design and synthesis of a new tumor-selective fluoropyrimidine carbamate, capecitabine. Bioorg. Med. Chem. 2000, 8, 1697-1706. [CrossRef]

33. Vorbrüggen, H.; Bennua, B. Nucleoside syntheses, XXV1) A new simplified nucleoside synthesis. Chem. Ber. 1981, 19, 1279-1286. [CrossRef]

34. Vorbrueggen, H. Adventures in Silicon-Organic Chemistry. Acc. Chem. Res. 1995, 28, 509-520. [CrossRef]

35. Bookser, B.C.; Raffaele, N.B. High-throughput five minute microwave accelerated glycosylation approach to the synthesis of nucleoside libraries. J. Org. Chem. 2007, 72, 173-179. [CrossRef] [PubMed]

36. Zhang, Q.; Sun, J.; Zhu, Y.; Zhang, F.; Yu, B. An Efficient Approach to the Synthesis of Nucleosides: Gold (I)-Catalyzed N-Glycosylation of Pyrimidines and Purines with Glycosyl ortho-Alkynyl Benzoates. Angew. Chem. Int. Ed. 2011, 50, 4933-4936. [CrossRef] [PubMed]

37. Shohda, K.; Wada, T.; Sekine, M. Detailed Studies on Trimethylselyl Triflate Mediated Glycosylation via a 3,5-O-(1,1,3,3-Tetraisopropyl-Disiloxane-1,3-diyl)-2-O-methylribofuranos-1-yl Trichloroacetimidate Intermediate. Nucleosides Nucleotides 1998, 17, 2199-2210. [CrossRef]

38. Liao, J.; Sun, J.; Yu, B. Effective synthesis of nucleosides with glycosyl trifluoroacetimidates as donors. Tetrahedron Lett. 2008, 49, 5036-5038. [CrossRef]

39. Liao, J.; Sun, J.; Yu, B. An improved procedure for nucleoside synthesis using glycosyl trifluoroacetimidates as donors. Carbohyd. Res. 2009, 344, 1034-1038. [CrossRef] [PubMed]

40. Liu, G.J.; Zhang, X.T.; Xing, G.W. Cheminform abstract: A general method for N-glycosylation of nucleobases promoted by (p-TOL) 2 SO/Tf $2 \mathrm{O}$ with thioglycoside as donor. ChemInform 2015, 46, 12803-12806.

41. Vorbrüggen, H.; Ruh-Pohlenz, C. Handbook of Nucleoside Synthesis; John Wiley \& Sons Inc.: Hoboken, NJ, USA, 2001.

Sample Availability: Samples of all the synthesized nucleoside are available from the authors.

(C) 2017 by the authors; licensee MDPI, Basel, Switzerland. This article is an open access article distributed under the terms and conditions of the Creative Commons Attribution (CC-BY) license (http://creativecommons.org/licenses/by/4.0/). 